\title{
Evidence of short-term belowground transfer of nitrogen from Acacia mangium to Eucalyptus grandis trees in a tropical planted forest
}

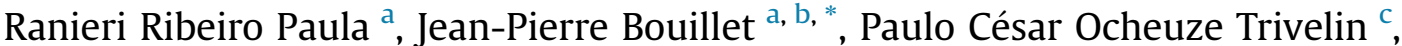 \\ Bernd Zeller ${ }^{\mathrm{d}}$, José Leonardo de Moraes Gonçalves ${ }^{\mathrm{a}}$, Yann Nouvellon ${ }^{\mathrm{a}}{ }^{\mathrm{b}}$, \\ Jean-Marc Bouvet ${ }^{\mathrm{e}}$, Claude Plassard ${ }^{\mathrm{f}}$, Jean-Paul Laclau ${ }^{\text {b, }}{ }^{\mathrm{g}}$ \\ ${ }^{a}$ USP-ESALQ Departamento de Ciências Florestais, Av. Pádua Dias, 11, CEP 13418-900 Piracicaba, SP, Brazil \\ ${ }^{\mathrm{b}}$ CIRAD, UMR Eco\&Sols, Écologie Fonctionnelle \& Biogéochimie des Sols \& Agroécosystèmes, 2 Place Viala, F34060 Montpellier, France \\ c USP-CENA, Divisão de Desenvolvimento de Técnicas Analíticas e Nucleares, Av. Centenário, 303, CEP 13416-000 Piracicaba, SP, Brazil \\ ${ }^{\mathrm{d}}$ INRA, UR 1138, Biogéochimie des Ecosystèmes Forestiers, Nancy, Champenoux, France \\ e CIRAD, UMR AGAP, Avenue Agropolis, 34398 Montpellier Cedex 5, France \\ ${ }_{\mathrm{f}}$ INRA, UMR Eco\&Sols, Écologie Fonctionnelle \& Biogéochimie des Sols \& Agroécosystèmes, 2 Place Viala, F34060 Montpellier, France \\ g UNESP, Departamento de Ciência Florestal, «Julio de Mesquita Filho», CEP 18610-300 Botucatu, SP, Brazil
}

\section{A R T I C L E I N F O}

Article history:

Received 21 May 2015

Received in revised form

24 July 2015

Accepted 16 August 2015

Available online 31 August 2015

\section{Keywords:}

${ }^{15} \mathrm{~N}$

Stem injection

Nitrogen facilitation

Exudates

Common mycorrhizal network

Nitrogen fixing trees

Acacia

Eucalyptus

\begin{abstract}
A B S T R A C T
The short-term belowground transfer of nitrogen from nitrogen-fixing trees to companion trees has never been studied in the field. A ${ }^{15} \mathrm{~N}$ pulse-labeling study was conducted in a mixed plantation of Acacia mangium and Eucalyptus grandis at the peak of leaf area, 26 months after planting. ${ }^{15} \mathrm{~N}-\mathrm{NO}_{3}^{-}$was injected into the stem of one big Acacia tree in three plots. ${ }^{15} \mathrm{~N}$ was traced over 2 months in the labeled Acacia tree as well as in neighboring Eucalyptus trees. For both species, young leaves were sampled, as well as fine roots and the rhizosphere at a distance of $0.75 \mathrm{~m}$ and $2.25 \mathrm{~m}$ from the labeled tree. The ${ }^{15} \mathrm{~N}$ atom\% was also determined in the wood, bark, branches and total foliage of the 3 labeled Acacia trees and 9 Eucalyptus trees, 60 days after labeling. Most of the leaves, fine roots and rhizosphere samples of both species were ${ }^{15} \mathrm{~N}$ enriched from 5 days after labeling. The $\delta^{15} \mathrm{~N}$ values were higher at a distance of $0.75 \mathrm{~m}$ than at $2.25 \mathrm{~m}$ in Acacia roots, but were similar at both distances in Eucalyptus roots and the rhizospheres. The wood and bark of Eucalyptus trees sampled at a distance of $6.2 \mathrm{~m}$ from the labeled Acacia trees were ${ }^{15} \mathrm{~N}$ enriched. This shows belowground $\mathrm{N}$ transfer from Acacia to Eucalyptus trees in the field during the first few days after labeling. This facilitation process may provide a significant amount of the nitrogen requirements of trees close to $\mathrm{N}$-fixing trees in mixed forests.
\end{abstract}

(c) 2015 Elsevier Ltd. All rights reserved.

\section{Introduction}

Recent studies show that associating nitrogen-fixing trees (NFT) and non-nitrogen-fixing species (non-NFS) can be beneficial for biomass production (Piotto, 2008; Forrester, 2014), soil carbon sequestration (Forrester et al., 2013; Blaser et al., 2014), soil fauna and microbial diversity (Bini et al., 2013; Manhães et al., 2013; Rachid et al., 2013) and soil nutrient availability (Voigtlaender et al., 2012; Blaser et al., 2014; Koutika et al., 2014). In tropical forest ecosystems, up to $90 \%$ of the nitrogen (N) in NFTs is derived

\footnotetext{
* Corresponding author. USP-ESALQ Departamento de Ciências Florestais, Av. Pádua Dias, 11, CEP 13418-900 Piracicaba, SP, Brazil. Tel.: +55 192105 8673; fax: +55192105 8601 .

E-mail address: jpbouillet@cirad.fr (J.-P. Bouillet).
}

from symbiotic fixation (Parrotta et al., 1996; Binkley and Giardina, 1997; Nygren et al., 2012). This $\mathrm{N}$ input is likely to improve the $\mathrm{N}$ status of associated non-NFS in forests established on degraded land (Nichols and Carpenter, 2006), agroforestry systems (Daudin and Sierra, 2008), mixed forest plantations (Binkley et al., 2003; Richards et al., 2010), and tropical forests (Batterman et al., 2013).

Decomposition of aboveground litter, pruning residues and roots is commonly considered to be the main N pathway from NFTs to non-NFS (Mafongoya et al., 1998; Munroe and Isaac, 2014). However, some studies have shown that direct belowground transfer of $\mathrm{N}$ without transformation of the $\mathrm{N}$ source (Munroe and Isaac, 2014) can also provide substantial amounts of $\mathrm{N}$ for non-NFS. Low-molecular $\mathrm{N}$ weight compounds, such as ammonium, nitrate and amino-acids (Wacquant et al., 1989; Paynel et al., 2001; Paynel and Cliquet, 2003), exuded by legume roots may be taken up by the 
companion plants (Jalonen et al., 2009; Fustec et al., 2010; Munroe and Isaac, 2014) provided that the plant uptake occurs before these compounds are taken up or mineralized by soil microorganisms, a process that is very fast (Cliquet et al., 1997; Lipson and Näsholm, 2001; Jones et al., 2004). Direct transfer of $\mathrm{N}$ can also occur via common mycorrhizal networks (CMN) (He et al., 2004, 2009; Kähkölä et al., 2012; Fellbaum et al., 2014).

Short-term (i.e within a few days or weeks) belowground transfer of $\mathrm{N}$ has been observed from NFTs to grasses and agricultural crops. The percentage of $\mathrm{N}$ of the grass Dichantium aristatum derived from transfer (\%NDFT) from N-fixing Gliricidia sepium seedlings ranged from 2 to $15 \%$ through root exudates, and from 0.5 to $2 \%$ via CMNs over 8 weeks in a greenhouse experiment (Jalonen et al., 2009). Sierra and Daudin (2010) estimated that, in the field, $45-80 \%$ of the $\mathrm{N}$ content in $D$. aristatum was derived from belowground transfer from $G$. sepium trees planted $1-5 \mathrm{~m}$ apart, 84 days after cutting the grass. After 21 days of contact between the root systems of Triticum durum seedlings and 2-month-old Acacia senegal seedlings growing in pots, the \%NDFT of the wheat reached $14 \%$ (Isaac et al., 2012). In a greenhouse experiment, Catchpoole and Blair (1990) estimated that $4 \%$ and $8 \%$ of the amount of labeled ${ }^{15} \mathrm{~N}$ in Leucaena leucocephala seedlings was transferred to Panicum maximum grass in 6 and 12 weeks, respectively. In a pot study carried out over 4 weeks, Rao and Giller (1993) estimated that 3-4\% of the amount of $\mathrm{N}$ in 3-month-old Leucaena diversifolia seedlings was transferred to Cenchrus ciliaris grass.

Although short-term belowground N transfer from NFTs to grass is now well documented, so far as we are aware (e.g. review from Chalk et al., 2014), such a fast transfer has never been confirmed between NFTs and non-NFTs in the field. The significance of this facilitation process in mixed species forests is still under discussion owing to the lack of experimental data (Chalk et al., 2014). In a 1month pot experiment, the percentage of $\mathrm{N}$ in 6-month-old Eucalyptus maculata seedlings that was derived from Casuarina cunninghamia plants via CMNs ranged from 1 to $9 \%$ depending on the nodulation status (He et al., 2004). This percentage varied from 4 to $30 \%$ in 12-month-old seedlings (He et al., 2005). Field studies suggest that $\mathrm{N}$ transfer could occur belowground from Inga edulis to Theobroma cacao (Nygren and Leblanc, 2009, 2015) and from Acacia sp. to Eucalyptus sp. (Hoogmoed et al., 2014) but the amount and the speed of the belowground $\mathrm{N}$ transfer were not estimated.

This study set out to assess whether there was short-term $\mathrm{N}$ transfer between NFTs and non-NFTs in a mixed plantation of Eucalyptus grandis Hill ex Maid. and Acacia mangium Wild. Both $E$. grandis and $A$. mangium are widely planted in tropical regions (FAO, 2010), and mixed plantations of Eucalyptus and Acacia might be an alternative to Eucalyptus monoculture (Forrester et al., 2013). A fast response of Eucalyptus trees to $\mathrm{N}$ fertilization has been observed in southeast Brazil (Gonçalves et al., 2013). Association with A. mangium may create facilitation processes involving atmospheric $\mathrm{N}_{2}$ fixation and $\mathrm{N}$ transfer to Eucalyptus trees (Bouillet et al., 2013). This experiment was designed to assess the possible short-term belowground $\mathrm{N}$-transfer from Acacia to Eucalyptus neighbors up to a distance of $6.2 \mathrm{~m}$ from ${ }^{15} \mathrm{~N}$ labeled Acacia trees. ${ }^{15} \mathrm{~N}-\mathrm{NO}_{3}^{-}$was injected in the stem of one big Acacia tree in three plots. The $\delta^{15} \mathrm{~N}$ values of recently-expanded leaves, fine roots and the rhizosphere (i.e soil adhering to the root, Hinsinger et al., 2003) of the two species were measured from March 5th to April 30th, 2012, and trees were destructively sampled 2 months after labeling. This study tested the hypotheses that (1) short-term belowground $\mathrm{N}$ transfer occurs between Acacia and Eucalyptus, which would be consistent, with the high densities of fine roots of both species and their intermingling in mixed plantations (Laclau et al., 2013a), and (2) N-transfer is not restricted to Eucalyptus trees located very close to Acacia trees as Eucalyptus trees are able to develop extensive root systems rapidly (O'Grady et al., 2005; Laclau et al., 2013b), to access resource-rich soil patches several meters from the trees (Bouillet et al., 2002; Sudmeyer and Simons, 2008; Silva et al., 2011).

\section{Material and methods}

\subsection{Site description}

The study was carried out at the Itatinga experimental station of São Paulo University, Brazil $\left(23^{\circ} 02^{\prime} \mathrm{S}, 48^{\circ} 38^{\prime} \mathrm{W}\right)$, at an elevation of $860 \mathrm{~m}$ asl. The soils were Ferralsols (FAO classification). The texture was very uniform below a depth of $1 \mathrm{~m}$ with clay content around $13 \%$ in the A1 layer and ranging from $20 \%$ to $25 \%$ between $1 \mathrm{~m}$ and $6 \mathrm{~m}$ in depth. The $0-10 \mathrm{~cm}$ soil layer had a cation exchange capacity (CEC) $<2$ cmolc $\mathrm{kg}^{-1}$ soil, with a mean total $\mathrm{N}$ concentration of $0.6 \mathrm{~g} \mathrm{~kg}^{-1}$ soil (Voigtlaender et al., 2012). The soils were typical of large areas planted with Eucalyptus in Brazil (Gonçalves et al., 2013). During the study period, the average air temperature was $20.4{ }^{\circ} \mathrm{C}$ and the cumulative rainfall, collected in an open area $100 \mathrm{~m}$ from the field trial, was $209.9 \mathrm{~mm}$ (Fig. 1). The soil water content was monitored in the first block of the field trial. The soil water content at $15 \mathrm{~cm}$ was measured every half hour using 3 Campbell CS616 probes, and the values were then averaged over the day.

\subsection{Site layout}

A complete randomized block design with 7 treatments and 4 blocks was set up in May 2003 to compare monospecific and mixed species stands of $A$. mangium and $E$. grandis. A detailed description of the original experimental layout can be found in Laclau et al. (2008). This study was carried out in 3 plots ( 1 plot per block of the original experiment) where the two species were planted alternately at $1.5 \mathrm{~m}$ spacing in the row, with $3 \mathrm{~m}$ between rows, giving a total stocking density of 2222 trees ha ${ }^{-1}$. Only the boles were harvested in May 2009 and the residues were spread uniformly within each plot. Eucalyptus stem wood biomass at harvest time was typical of productive commercial plantations (Bouillet et al., 2013). A. mangium and E. grandis seedlings were re-planted

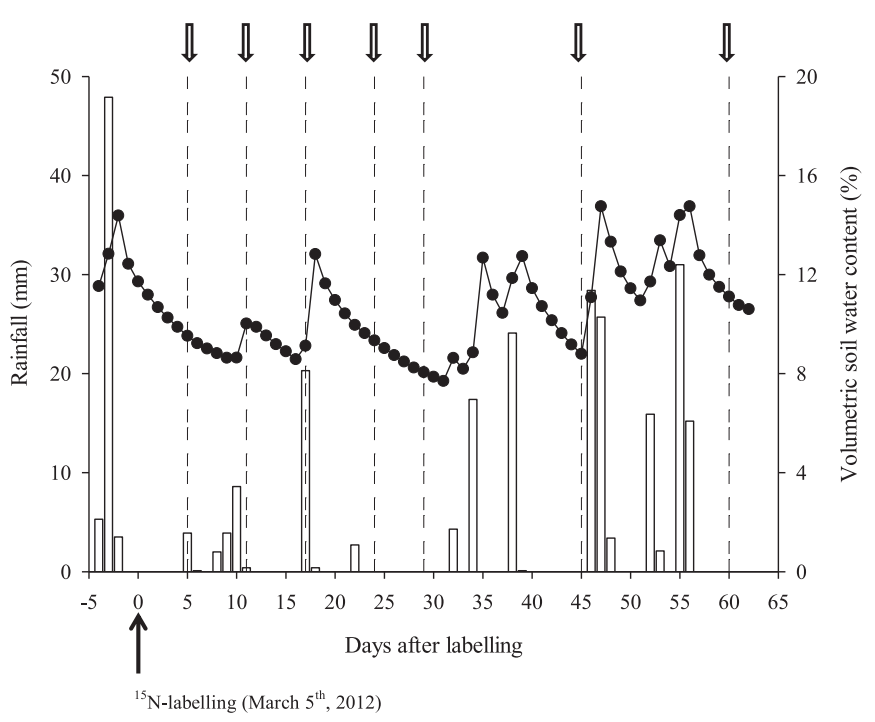

Fig. 1. Rainfall (vertical bars) and volumetric soil water content (black circles) at a depth of $15 \mathrm{~cm}$ over the 60 day study period. Sampling dates are indicated by arrows and dotted lines. Five days after Acacia labeling, there was rainfall after samples had been collected. 
in the same plots on November 2009. Factorial fertilization trials at the study site and in nearby commercial forests on the same soil type showed that the amounts of nutrients applied were nonlimiting for Eucalyptus tree growth (Laclau et al., 2009), except for $\mathrm{N}$. The fertilizers applied on planting were $40 \mathrm{~g} \mathrm{P}$ plant $^{-1}$ (buried at $20 \mathrm{~cm}$ from the plants), as well as $9 \mathrm{~g} \mathrm{plant}^{-1} \mathrm{~K}, 3 \mathrm{~g}$ plant $^{-1} \mathrm{~B}, 6 \mathrm{~g}$ plant ${ }^{-1} \mathrm{Fe}, 3 \mathrm{~g}$ plant ${ }^{-1} \mathrm{Zn}$, and $1 \mathrm{~g} \mathrm{plant}^{-1} \mathrm{Mn}$. Additional potassium was applied at a rate of $115 \mathrm{~kg} \mathrm{ha}^{-1} \mathrm{~K} 6$ months after planting.

\section{3. ${ }^{15} \mathrm{~N}$ labeling of Acacia trees}

In each plot ( 3 plots in separate blocks), a ${ }^{15} \mathrm{~N}$ labeled solution was injected into the stem of one Acacia tree 26 months after planting. This corresponded to the peak leaf area in these fastgrowing plantations (le Maire et al., 2013). The labeled trees had a single stem and were selected from the $10 \%$ biggest acacias in each stand (mean height of $7.4 \mathrm{~m}$ ). No tree mortality was observed within a radius of $6.2 \mathrm{~m}$ around the labeled Acacia trees (Fig. 2). The injection technique was based on a passive uptake design (Proe et al., 2000) with ${ }^{15} \mathrm{~N}$ injected into the xylem vessels. For each Acacia tree to be labeled, a hole $(6 \mathrm{~mm}$ in diameter and $25 \mathrm{~mm}$ in depth) was drilled into the stem, $1 \mathrm{~m}$ above the ground. The drill was lubricated using distilled water to prevent damage to the xylem vessels. Immediately after removing the drill, a polyethylene tube ( $6 \mathrm{~mm}$ in diameter), attached to a bottle containing $100 \mathrm{ml}$ of distilled water, was pushed $20 \mathrm{~mm}$ into the drilled hole (Fig. 3). This bottle was then connected to a second bottle containing $0.9 \mathrm{~g}$ of $\mathrm{N}$ (98 atom\% ${ }^{15} \mathrm{~N}-\mathrm{NO}_{3}^{-}$) as potassium nitrate, dissolved in $400 \mathrm{ml}$ of distilled water. Using two bottles in this way prevented any litter or soil contamination by ${ }^{15} \mathrm{~N}$ when inserting the tube into the hole. ${ }^{15} \mathrm{~N}$ contamination was also avoided by packing the bark around the tube with non-toxic mineral putty (Terostat ${ }^{\circledR}$ ) to prevent the solution leaking, and by covering the soil around the labeled trees with a plastic bag. In addition, a cellulose sheet was placed just below the hole in the stem to check that there were no leaks. The $500 \mathrm{ml}$ solution was absorbed by the stem in $12-36 \mathrm{~h}$ depending on the tree. When the solution had been completely absorbed, the hole was filled with Terostat putty. A few Acacia leaves fell during the study period and were removed from the experimental area within $24 \mathrm{~h}$ of falling.

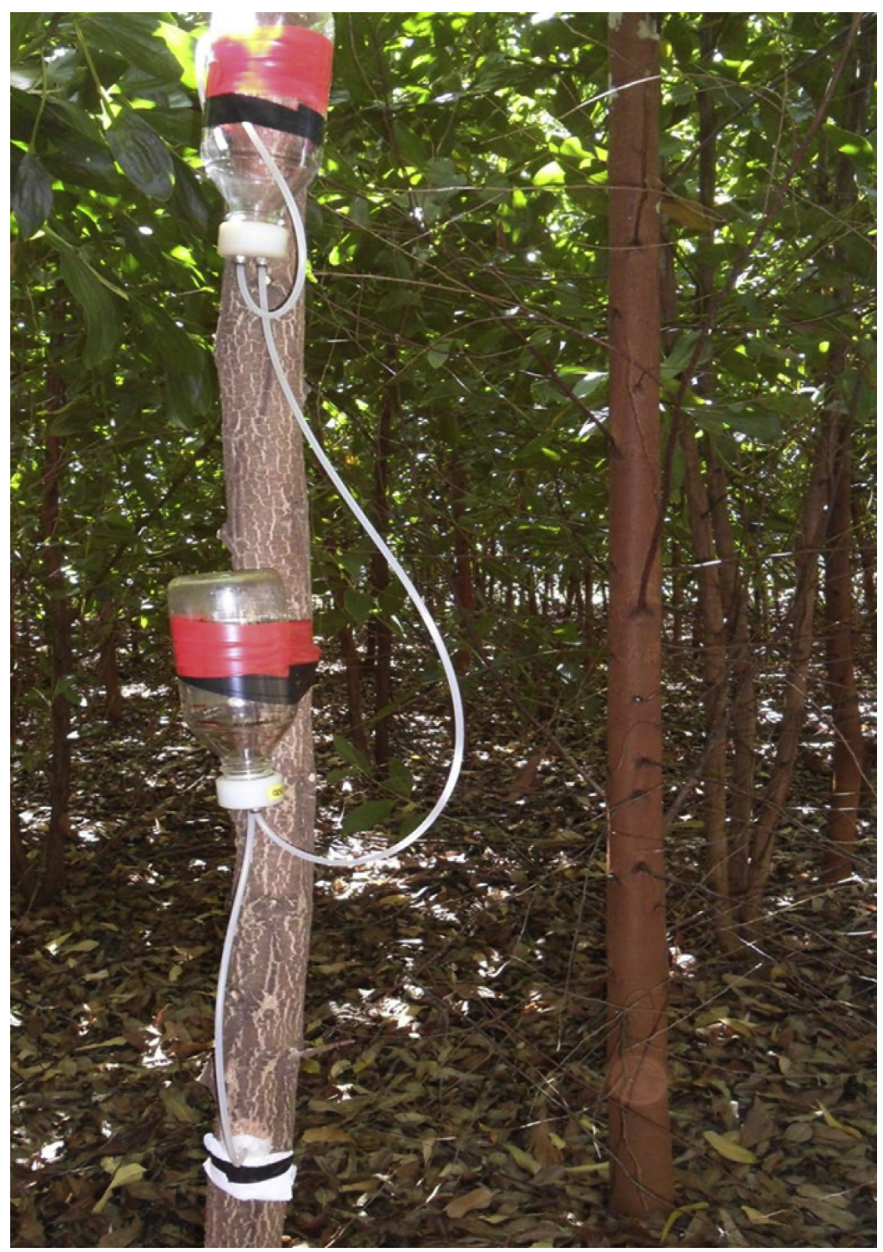

Fig. 3. ${ }^{15} \mathrm{~N}$-labeling by injection into the stem of 26 -month-old Acacia mangium (block 1). The bottle at the bottom contained $100 \mathrm{ml}$ distilled water before connection to the second bottle above which contained 0.9 g of N (98 atom\% ${ }^{15} \mathrm{~N}-\mathrm{NO}_{3}^{-}$) dissolved in $400 \mathrm{ml}$ of distilled water.

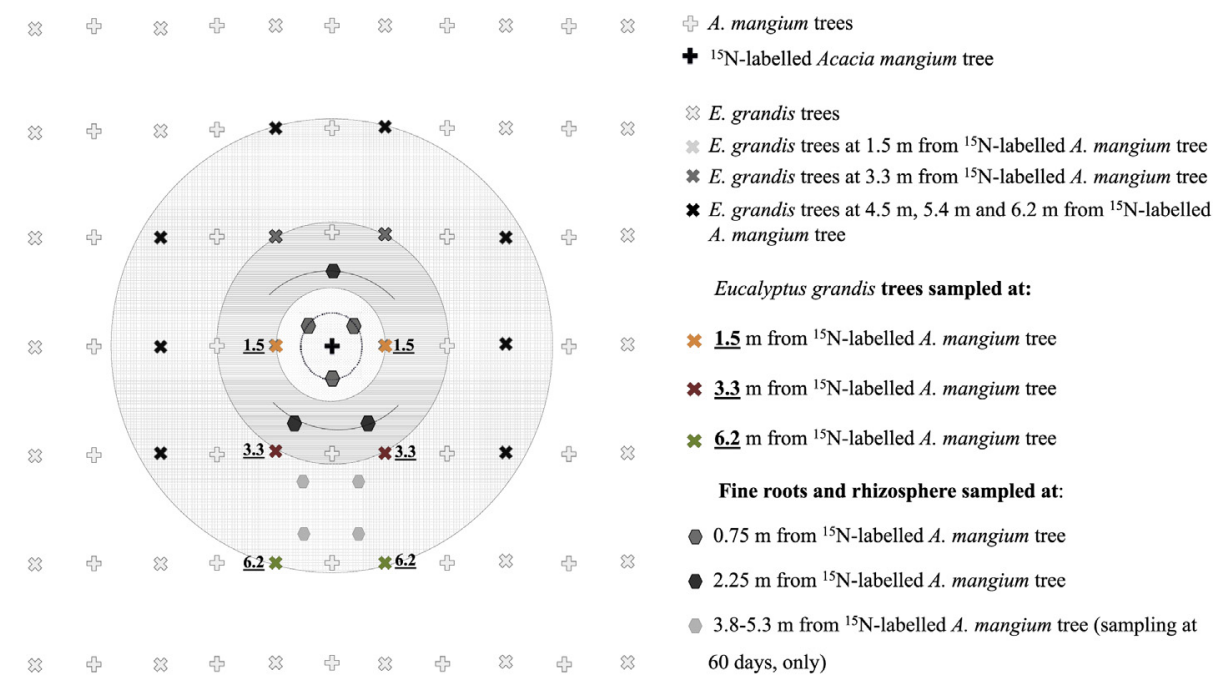

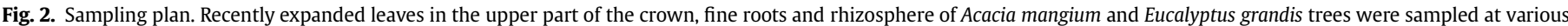

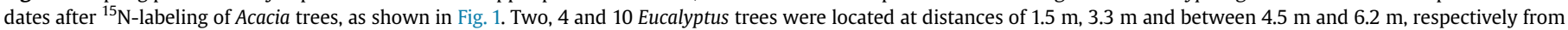
the ${ }^{15} \mathrm{~N}$-labeled Acacia trees. The areas between 0 and $1.5 \mathrm{~m}$ from the labeled Acacia trees, $1.5-3 \mathrm{~m}$ and $3-6.2 \mathrm{~m}$ were $7.1 \mathrm{~m}^{2}, 21.2 \mathrm{~m}^{2}$ and $92.5 \mathrm{~m}^{2}$, respectively. 


\subsection{Sampling}

In each block, scaffolding was used to sample recently expanded leaves (hereafter referred to as young leaves) in the upper third of the crown of the ${ }^{15} \mathrm{~N}$-labeled acacia and of 3 sets of Eucalyptus trees (6 per block) located at distances of $1.5 \mathrm{~m}, 3.3 \mathrm{~m}$ and $6.2 \mathrm{~m}$ from the acacia (Fig. 2). The mean height of the Eucalyptus trees across the 3 blocks was $12.6 \mathrm{~m}, 10.3 \mathrm{~m}$ and $12.6 \mathrm{~m}$ at distances of $1.5 \mathrm{~m}, 3.3 \mathrm{~m}$ and $6.2 \mathrm{~m}$ respectively from the labeled Acacia trees. Five, 11, 17, 24, 29, 45 and 60 days after ${ }^{15} \mathrm{~N}$ labeling, 3 leaves were collected from each labeled acacia in each block and 5 leaves from each sampled Eucalyptus tree at different angles around the tree. These leaf samples were then bulked for each tree. On the same dates, three soil samples were collected from each block using a PVC tube ( $5 \mathrm{~cm}$ in diameter and $10 \mathrm{~cm}$ in length) at distances of $0.75 \mathrm{~m}$ and $2.25 \mathrm{~m}$ from the labeled Acacia trees (Fig. 3). These soil samples were then bulked for each distance and for each block. Sixty days after ${ }^{15} \mathrm{~N}$ labeling, four additional soil samples were taken at a distance of 3.8 and $5.3 \mathrm{~m}$ from each labeled Acacia tree (Fig. 2) and bulked. The soil samples were taken immediately to the laboratory to separate the fine roots (diameter $<2 \mathrm{~mm}$ ) of each species as in previous studies (Silva et al., 2009; Laclau et al., 2013a). Small fragments of roots were discarded and only the fine roots that could be clearly identified as belonging to one or other of the two species (fine Eucalyptus roots had a higher degree of branching and were darker than fine Acacia roots (Laclau et al., 2013a)) were used for chemical and isotopic analyses. The rhizosphere was then collected by gently shaking off any soil still adhering to the roots. Before labeling, samples had been taken in the same way to measure the $\delta^{15} \mathrm{~N}$ background values of the young leaves, the fine roots and the rhizosphere of the two species, except for young Eucalyptus leaves which were bulked for each distance from the Acacia trees that were to be labeled ( 3 samples of Eucalyptus tree leaves per block).

At the end of the experiment, the labeled Acacia tree and one Eucalyptus tree at each distance from the labeled Acacia were harvested in each block ( 3 Acacia trees and 9 Eucalyptus trees in total). The $\mathrm{N}$ concentrations and $\delta^{15} \mathrm{~N}$ values of leaves, living branches, stem wood and stem bark were determined for all the sampled trees. A detailed description of the methodology can be found in Bouillet et al. (2008). $\delta^{15} \mathrm{~N}$ background values for each tree compartment (Table 1) had been measured for one Acacia tree and one Eucalyptus tree per block just before labeling.

\subsection{Sample preparation and isotopic analyses}

The fine roots were washed in tap water. All plant materials were dried at $65{ }^{\circ} \mathrm{C}$ to constant weight. The bark, wood and branches were ground in a Wiley mill $(0.8 \mathrm{~mm}$ mesh $)$ and the leaves, fine roots, and rhizosphere were ground in a porcelain mortar. The $\delta^{15} \mathrm{~N}$ values and $\mathrm{N}$ concentration were determined using a Hydra 20-20 mass spectrometer coupled to an automatic N analyzer (ANCA-GSL, SERCON Co., Crewe, UK) using $10 \mathrm{mg}$ of dry plant material samples and $15 \mathrm{mg}$ of soil samples (Barrie and Prosser, 1996). The precision of the isotopic measurements was $0.001{ }^{15} \mathrm{~N}$ atom\%. The $\delta^{15} \mathrm{~N}$ value of a given sample was expressed as:

$\delta^{15} \mathrm{~N}_{\text {sample }}(\%$ o $)=\left(\frac{\left({ }^{15} \mathrm{~N} /{ }^{14} \mathrm{~N}\right) \text { sample }-\left({ }^{15} \mathrm{~N} /{ }^{14} \mathrm{~N}\right) \text { air }}{\left({ }^{15} \mathrm{~N} /{ }^{14} \mathrm{~N}\right) \text { air }}\right) \times 1000$

\section{6. $N$ transfer calculations}

\subsubsection{Mass balance}

The proportion of the ${ }^{15} \mathrm{~N}$ injected into the Acacia stem that was transferred to the foliage, branches, stem wood and stem bark of the Eucalyptus trees sampled at the end of the study period was estimated as:

$$
\begin{aligned}
\mathrm{P}_{\text {compartment }}(\%)= & \left(\mathrm { N } \text { content } * \left({ }^{15} \mathrm{~N} \text { atom } \%_{60}\right.\right. \text { days } \\
& \left.\left.-{ }^{15} \mathrm{~N} \text { atom } \%_{0} \text { day }\right) /{ }^{15} \mathrm{~N}\right) * 100
\end{aligned}
$$

Where:

- $\mathrm{N}$ content is the $\mathrm{N}$ content 60 days after Acacia labeling

$-{ }^{15} \mathrm{~N}$ atom\%60 days is the ${ }^{15} \mathrm{~N}$ atom\% 60 days after Acacia labeling

- ${ }^{15} \mathrm{~N}$ atom\% day is the ${ }^{15} \mathrm{~N}$ atom\% before Acacia labeling

$-{ }^{15} \mathrm{~N}$ is the mass of ${ }^{15} \mathrm{~N}$ injected $=0.882 \mathrm{~g}$

The underlying assumption of Eq. (2) is that the $\mathrm{N}$ content of the Eucalyptus compartments did not change from the beginning to the end of the experiment, or that such change was negligible in relation to the ${ }^{15} \mathrm{~N}$ enrichment. A marked increase in $\mathrm{N}$ content during the study period could lead to a significant underestimation of $\mathrm{P}_{\text {compartment }}(\%)$.

The proportion of the injected ${ }^{15} \mathrm{~N}$ transferred to the aboveground compartments of a given Eucalyptus tree was estimated as:

$\mathrm{P}_{\text {above }}(\%)=\mathrm{P}_{\text {foliage }}(\%)+\mathrm{P}_{\text {branches }}(\%)+\mathrm{P}_{\text {wood }}(\%)+\mathrm{P}_{\text {bark }}(\%)$

The proportion of ${ }^{15} \mathrm{~N}$ transferred to the foliage, branches, wood and bark of Eucalyptus trees within a $6.2 \mathrm{~m}$ radius around the labeled Acacia was calculated on the assumption that 2, 4 and 10 Eucalyptus trees were located at $1.5 \mathrm{~m}, 3.3 \mathrm{~m}$ and $4.5-6.2 \mathrm{~m}$, respectively (Fig. 3):

$$
\begin{aligned}
\mathrm{P}_{\text {above_(0-6.2 m })}(\%)= & 2 \mathrm{P}_{\text {above_1.5 } \mathrm{m}}(\%)+4 \mathrm{P}_{\text {above_3.3 } \mathrm{m}(\%)} \\
& +10 \mathrm{P}_{\text {above_6. }} \mathrm{m}(\%)
\end{aligned}
$$

Table 1

\begin{tabular}{|c|c|c|c|c|c|c|}
\hline \multirow[t]{3}{*}{ Compartments } & \multirow{2}{*}{\multicolumn{2}{|c|}{ A. mangium }} & \multicolumn{4}{|l|}{ E. grandis } \\
\hline & & & \multirow[t]{2}{*}{ Background } & \multicolumn{3}{|c|}{ Distance from A. mangium } \\
\hline & Background & 60 days & & $1.5 \mathrm{~m}$ (60 days) & 3.3 m (60 days) & $6.2 \mathrm{~m}$ (60 days) \\
\hline Total foliage & $3.90 \pm 0.78$ & $2946.03^{*} \pm 1066.13$ & $0.00 \pm 0.00$ & $0.35 a \pm 0.37$ & $-0.29 b \pm 0.24$ & $-0.34 b \pm 0.22$ \\
\hline Branches & $4.33 \pm 0.84$ & $2364.20^{*} \pm 395.73$ & $0.01 \pm 0.01$ & $0.64 \mathrm{a} \pm 0.64$ & $-0.05 a \pm 0.78$ & $-0.24 a \pm 0.45$ \\
\hline Wood & $8.10 \pm 1.08$ & $2169.22 * \pm 495.32$ & $0.01 \pm 0.00$ & $4.13^{*} \mathrm{a} \pm 1.11$ & $2.82^{*} \mathrm{a} \pm 0.87$ & $2.74^{*} \mathrm{a} \pm 0.75$ \\
\hline Bark & $5.15 \pm 0.67$ & $971.27^{*} \pm 66.95$ & $0.01 \pm 0.00$ & $4.12 * a \pm 1.26$ & $3.04 * a \pm 0.86$ & $3.17^{*} \mathrm{a} \pm 0.90$ \\
\hline
\end{tabular}

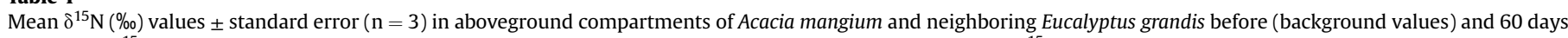

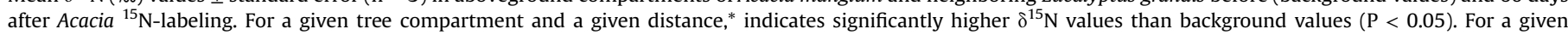
Eucalyptus tree compartment, different letters indicate significant differences between distances $(\mathrm{P}<0.05)$. 
Where:

Pabove_1.5m (\%), Pabove_3.3m (\%), Pabove_6.2m (\%) are the values of Pabove (\%) for the Eucalyptus trees at $1.5 \mathrm{~m}, 3.3 \mathrm{~m}$, and $6.2 \mathrm{~m}$ from the labeled Acacia tree.

The proportion of injected ${ }^{15} \mathrm{~N}$ transferred to fine Eucalyptus roots within a radius of $6.2 \mathrm{~m}$ around the labeled Acacia trees was estimated as:

$$
\begin{aligned}
P_{\text {roots_ }(0-6.2 \mathrm{~m})}(\%)= & 7.1 \mathrm{P}_{\text {roots_0.75 } \mathrm{m}}(\%)+21.2 \mathrm{P}_{\text {roots_ } 2.25 \mathrm{~m}}(\%) \\
& +92.5 \mathrm{P}_{\text {roots }} 3.8-5.3 \mathrm{~m}(\%)
\end{aligned}
$$

Where $P_{\text {roots_i }}(\%)$ is defined as:

$$
\begin{aligned}
\mathrm{P}_{\text {roots_i }}(\%)= & \left(\mathrm { FR } _ { \mathrm { N } } \text { content } * \left({ }^{15} \mathrm{~N} \text { atom\% } 60\right.\right. \text { days } \\
& \left.\left.-{ }^{15} \mathrm{~N} \text { atom\% } \%_{0 \text { day }}\right) / 0.882\right) * 100
\end{aligned}
$$

Where:

- $\mathrm{FR}_{\mathrm{N}}$ is the $\mathrm{N}$ content per $\mathrm{m}^{2}$ of fine roots at a distance i from the labeled Acacia tree

- ${ }^{15} \mathrm{~N}$ atom\% 60 days is the ${ }^{15} \mathrm{~N}$ atom\% of the fine roots collected 60 days after labeling

- ${ }^{15} \mathrm{~N}$ atom\% $\%$ day is the ${ }^{15} \mathrm{~N}$ atom\% of the fine roots collected before labeling

- $\mathrm{FR}_{\mathrm{N}}$ was estimated by multiplying the mean $\mathrm{N}$ concentration in fine roots, collected 60 days after labeling, by a fine root biomass density of $178.5 \mathrm{~g} \mathrm{~m}^{-2}$ as estimated for the $0-2 \mathrm{~m}$ soil layer at the same site in plots with the same proportion of Eucalyptus and Acacia trees (Laclau et al., 2013a). The area considered was $7.1 \mathrm{~m}^{2}$ between 0 and $1.5 \mathrm{~m}, 21.2 \mathrm{~m}^{2}$ between $1.5 \mathrm{~m}$ and $3 \mathrm{~m}$, and $92.5 \mathrm{~m}^{2}$ between $3 \mathrm{~m}$ and $6.2 \mathrm{~m}$ for fine Eucalyptus roots sampled at $0.75 \mathrm{~m}, 2.25 \mathrm{~m}$, and $3.8-5.3 \mathrm{~m}$, respectively (Fig. 3).

The proportion of injected ${ }^{15} \mathrm{~N}$ transferred to Eucalyptus trees within a radius of $6.2 \mathrm{~m}$ around labeled Acacia trees was estimated as:

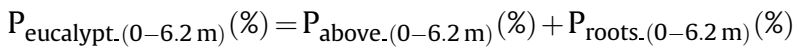

\subsection{2. $N$ derived from transfer}

The proportion of Eucalyptus $\mathrm{N}$ derived from transfer (\%NDFT) from Acacia was estimated at the collection date using equation (8) (Jalonen et al., 2009; Isaac et al., 2012):

$\% \operatorname{NDFT}(\mathrm{t})=\left(\frac{\delta^{15} \mathrm{~N}_{\mathrm{Euc}}(0)-\delta^{15} \mathrm{~N}_{\mathrm{Euc}}(\mathrm{t})}{\delta^{15} \mathrm{~N}_{\mathrm{Euc}}(0)-\delta^{15} \mathrm{~N}_{\mathrm{Ac}}(\mathrm{t})}\right) \times 100$

Where:

- $\delta^{15} \mathrm{~N}_{\text {Euc }}$ is the $\delta^{15} \mathrm{~N}$ value of fine $E$. grandis roots collected at $0.75 \mathrm{~m}$ or $2.25 \mathrm{~m}$ from the ${ }^{15} \mathrm{~N}$ labeled Acacia.

- $\delta^{15} \mathrm{~N}_{\mathrm{Ac}}$ is the $\delta^{15} \mathrm{~N}$ value of fine $A$. mangium roots collected at $0.75 \mathrm{~m}$ or $2.25 \mathrm{~m}$ from the ${ }^{15} \mathrm{~N}$ labeled Acacia.

- $\delta^{15} \mathrm{~N}_{\text {Euc }}(0)$ and $\delta^{15} \mathrm{~N}_{\text {Euc }}(\mathrm{t})$ are the $\delta^{15} \mathrm{~N}$ values of fine Eucalyptus roots before $A$. mangium labeling, and at the end of each collection date, respectively

- $\delta^{15} \mathrm{~N}_{\mathrm{Ac}}(\mathrm{t})$ is the $\delta^{15} \mathrm{~N}$ value of fine Acacia roots at the end of each study period.

The mean value of \%NDFT was calculated for each sampling date ( 2 distances $\times 3$ blocks). The mean value of \%NDFT for the 60 day study period was calculated as the mean of \%NDFT for each sampling date $(n=7)$.

\subsection{Statistical analyses}

For each collection date, each species and each distance $(0.75 \mathrm{~m}$ and $2.25 \mathrm{~m}$, and $3.8-5.3 \mathrm{~m}$ at 60 days), the ${ }^{15} \mathrm{~N}$ enrichment of the tree material and rhizosphere was tested against ${ }^{15} \mathrm{~N}$ background values using a one-tailed paired t test (analysis 1 ). For each species and each collection date, a two-way analysis of variance was used to test for differences in the $\delta^{15} \mathrm{~N}$ values of tree components and rhizosphere due to the distances from the labeled Acacia trees ( $0.75 \mathrm{~m}, 2.25 \mathrm{~m}$, and $3.8-5.3 \mathrm{~m}$ at 60 days) and blocks (analysis 2). A linear mixed model was used (analysis 3 ) to test the effects of the distance from the labeled Acacia tree and the blocks (as fixed effects) as well as the sampling dates (as random effects) on the $\delta^{15} \mathrm{~N}$ values of fine Acacia roots, Acacia rhizosphere, fine Eucalyptus roots, Eucalyptus rhizosphere and young Eucalyptus leaves. Additionally, for each sampling date, the increase in $\mathrm{N}$ concentration in Acacia leaves and fine roots and leaves after ${ }^{15} \mathrm{~N}$ stem injection was tested against the initial $\mathrm{N}$ concentration values using a one-tailed paired $\mathrm{t}$ test (analysis 4). The GLM procedure of SAS 9.3 was used (SAS Institute, Cary, NC, USA) for the fixed effects models. ASReml (Gilmour et al., 2005) was used for the linear mixed models. The homogeneity of variances was tested using Levene's test, and the normal distribution of residuals was tested using Shapiro-Wilks test. The values were log-transformed when variances were unequal. Bonferroni's test was used for comparisons for fixed effects models. Wald's test was used for mixed effects models (Kenward and Roger, 1997). The significance level was 0.05.

\section{Results}

\section{1. $\delta^{15} \mathrm{~N}$ in labeled Acacia trees}

The $\delta^{15} \mathrm{~N}$ of the young leaves increased significantly after labeling Acacia trees (analysis 1 ) to reach values $>650 \%$ from 5 days after labeling (Fig. 4). The $\delta^{15} \mathrm{~N}$ values within young leaves varied between the labeled Acacia trees and between the sampling dates, from 11 days after labeling. Fine Acacia roots had higher mean $\delta^{15} \mathrm{~N}$ values than the background values of $\delta^{15} \mathrm{~N}$ at distances of $0.75 \mathrm{~m}$ and $2.25 \mathrm{~m}$ from the labeled Acacia trees (Fig. 5a) with significant differences (analysis 1 ) on five collection dates at $0.75 \mathrm{~m}$ and two collection dates at $2.25 \mathrm{~m}$. The $\delta^{15} \mathrm{~N}$ values in fine Acacia roots were higher at a distance of $0.75 \mathrm{~m}$ from the ${ }^{15} \mathrm{~N}$ labeled Acacia trees than at a distance of $2.25 \mathrm{~m}$ (analysis 3), with significant differences

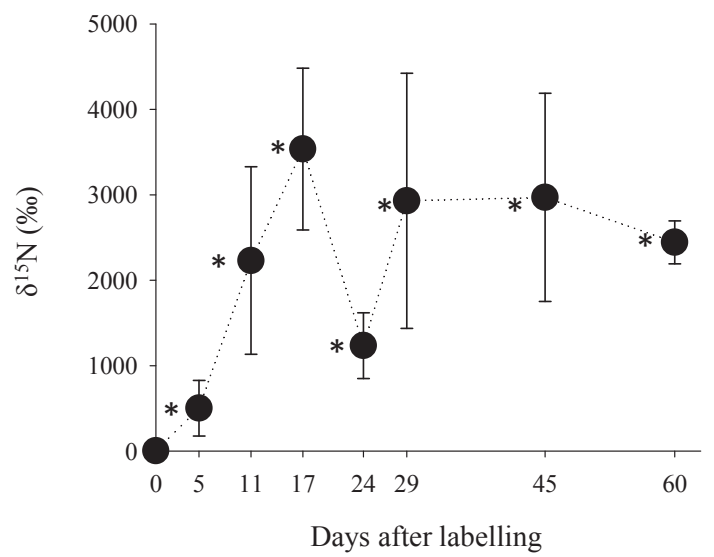

Fig. 4. $\delta^{15} \mathrm{~N}$ values of Acacia mangium young leaves after ${ }^{15} \mathrm{~N}$ injection in $A$. mangium stem. Background values are indicated for the labeling date (day 0). Vertical bars indicate standard errors between blocks $(\mathrm{n}=3)$. For a given collection date, ${ }^{*}$ indicates significant differences from $\delta^{15} \mathrm{~N}$ background values $(\mathrm{P}<0.05)$. The mean background $\delta^{15} \mathrm{~N}$ value was $2.68 \pm 0.40 \%(\mathrm{n}=3)$. 


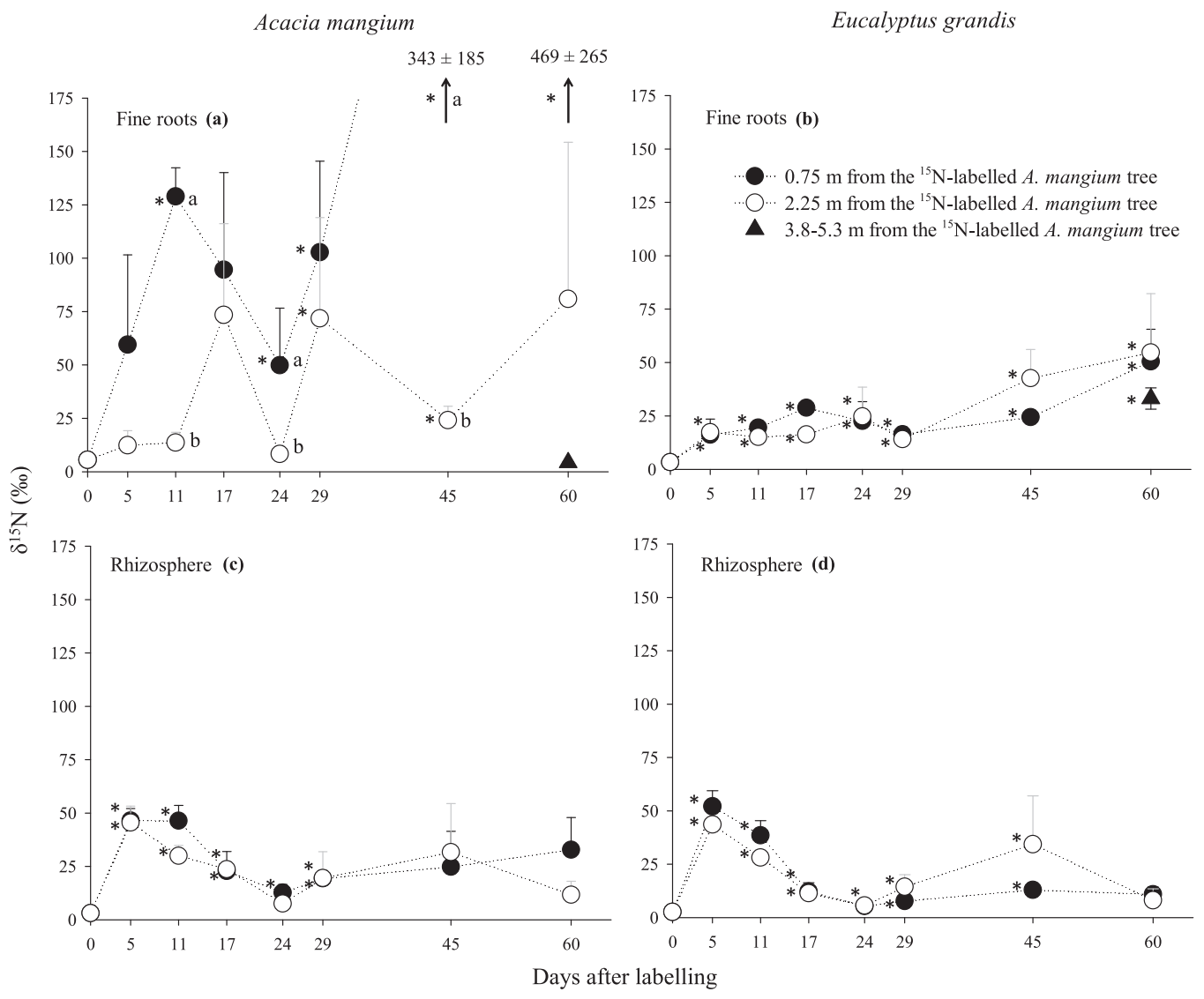

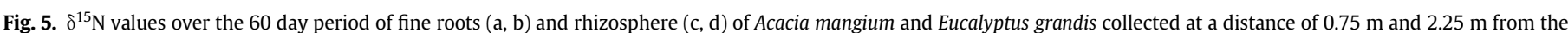

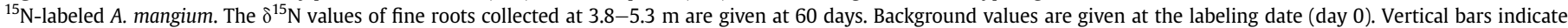

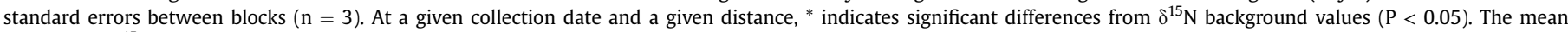

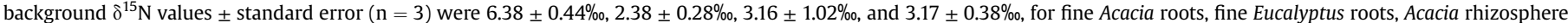

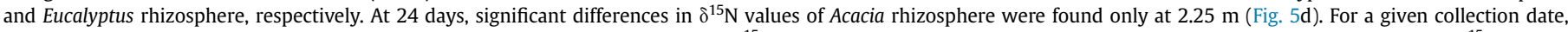

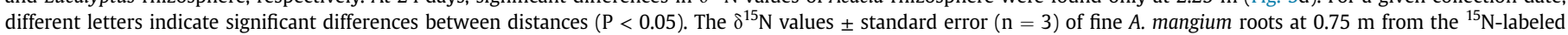
A. mangium tree were $343 \pm 185 \%$ and $469 \pm 265 \%$, at 45 and 60 days respectively.

between the two distances (analysis 2) 11, 24, and 45 days after labeling (Fig. 5a). 60 days after labeling, fine Acacia roots had lower mean $\delta^{15} \mathrm{~N}$ values than $\delta^{15} \mathrm{~N}$ background values at a distance of 3.8-5.3 $\mathrm{m}$ from the labeled trees (Fig. 5a), and all the aboveground compartments of the labeled Acacia trees had much higher $\delta^{15} \mathrm{~N}$ values (Table 1 ).

\section{2. $\delta^{15} \mathrm{~N}$ in the rhizosphere}

The rhizosphere of both species had higher $\delta^{15} \mathrm{~N}$ values after labeling than the background values, at all distances from the labeled Acacia trees, with significant differences (analysis 1) on most of the sampling dates (Fig. $5 c, d$ ). The ${ }^{15} \mathrm{~N}$ enrichment of the rhizosphere was not significantly affected by the sampling distances, for all species and on all collection dates (analyses 2 and 3). The time series of $\delta^{15} \mathrm{~N}$ values in the rhizosphere showed a similar pattern for both species with a rapid initial increase after labeling, followed by a marked decrease from 5 to 24 days. Over the study period, the Eucalyptus rhizosphere had only slightly lower ${ }^{15} \mathrm{~N}$ enrichment than the Acacia rhizosphere with mean $\delta^{15} \mathrm{~N}$ values of $20.4 \%$ and $26.8 \%$, respectively.

\section{3. $\delta^{15} N$ in Eucalyptus trees}

Fine Eucalyptus roots were significantly ${ }^{15} \mathrm{~N}$-enriched (analysis 1) at distances of $0.75 \mathrm{~m}$ and $2.25 \mathrm{~m}$ from the labeled Acacia trees from 5 days after labeling, as well as at a distance of $3.8-5.3 \mathrm{~m}$ from the labeled Acacia trees at 60 days after labeling (Fig. 5b). Over the study period, the change in $\delta^{15} \mathrm{~N}$ values of the fine Eucalyptus roots was not significantly different at distances of $0.75 \mathrm{~m}$ and $2.25 \mathrm{~m}$ from the labeled Acacia trees (analyses 2 and 3). 60 days after labeling fine Eucalyptus roots had mean $\delta^{15} \mathrm{~N}$ values of $50 \%$ at a distance of $0.75 \mathrm{~m}$ from the labeled Acacia trees, $55 \%$ at $2.25 \mathrm{~m}$, and $33 \%$ at $3.8-5.3 \mathrm{~m}$, and the effect of the distance from the labeled tree was not significant (Fig. 5b).

On most of the sampling dates, the $\delta^{15} \mathrm{~N}$ values in young Eucalyptus leaves were higher than the background values (Fig. 6). Differences were significant (analysis 1) 5 days after labeling at a distance of $1.5 \mathrm{~m}$ from the labeled Acacia trees and 45 and 60 days after labeling, at distances of $3.3 \mathrm{~m}$ and $6.2 \mathrm{~m}$. There were no significant differences in the $\delta^{15} \mathrm{~N}$ values of young Eucalyptus leaves at different distances from the labeled Acacia trees (analyses 2 and 3 ). However, the mean $\delta^{15} \mathrm{~N}$ values of $2.95 \%$ at $1.5 \mathrm{~m}, 2.55 \%$ at $3.2 \mathrm{~m}$, and $2.39 \%$ at $6.2 \mathrm{~m}$ showed a slight decrease with the distance from the labeled Acacia trees. The $\delta^{15} \mathrm{~N}$ values of young Eucalyptus leaves also decreased slightly with distance from $1.5 \mathrm{~m}$ to $6.2 \mathrm{~m}$ from the labeled Acacia trees on four of the seven collection dates.

60 days after labeling the Acacia trees, the wood and bark of neighboring Eucalyptus trees had a significantly higher $\delta^{15} \mathrm{~N}$ (analysis 1) but without significant variation with distance (analysis 2) from the labeled Acacia trees (Table 1). The branches and the total foliage of the same Eucalyptus trees did not have 


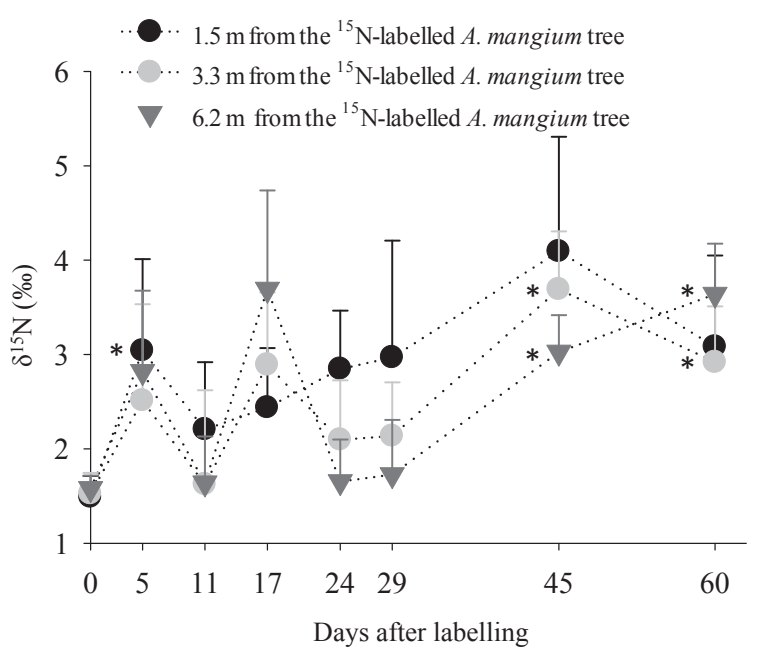

Fig. 6. $\delta^{15} \mathrm{~N}$ values over the 60 day period of young leaves of Eucalyptus grandis pairs located at a distance of $1.5 \mathrm{~m}, 3.3 \mathrm{~m}$ and $6.2 \mathrm{~m}$ from the ${ }^{15} \mathrm{~N}$-labeled Acacia mangium. The background values are indicated for the labeling date (day 0 ). Vertical bars indicate standard errors between blocks $(\mathrm{n}=3)$. At a given collection date and a given distance, * indicates significant differences with $\delta^{15} \mathrm{~N}$ background values $(\mathrm{P}<0.05)$. The mean background $\delta^{15} \mathrm{~N}$ values \pm standard error $(\mathrm{n}=3)$ were $1.49 \pm 0.36 \%, 1.53 \pm 0.35 \%$, and $1.58 \pm 0.21 \%$, at a distance of $1.5 \mathrm{~m}, 3.3 \mathrm{~m}$ and $6.2 \mathrm{~m}$, respectively.

significantly higher $\delta^{15} \mathrm{~N}$. However, the $\delta^{15} \mathrm{~N}$ values for the total foliage were significantly higher at a distance of $1.5 \mathrm{~m}$ than at distances of $3.3 \mathrm{~m}$ and $6.2 \mathrm{~m}$ from the labeled Acacia trees (analysis 2).

\section{4. ${ }^{15} \mathrm{~N}$ transferred to Eucalyptus trees}

The percentage of the ${ }^{15} \mathrm{~N}$ injected into Acacia trees that was transferred within 60 days to the Eucalyptus trees within a radius of $6.2 \mathrm{~m}$ around the labeled Acacia trees was estimated at $3.33 \pm 1.24 \%$ (2.25\%, $0.85 \%, 0.16 \%, 0.04 \%$ and $0.03 \%$ for fine roots, wood, bark, foliage and branches, respectively).

The percentage of $\mathrm{N}$ of Eucalyptus trees derived from transfer (\% NDFT) from Acacia trees estimated using Eq. (8) ranged from $15.8 \%$ to $78.2 \%$ depending on the sampling dates, with an average value of $43.2 \%$ over the experimental period of 60 days (Fig. 7).

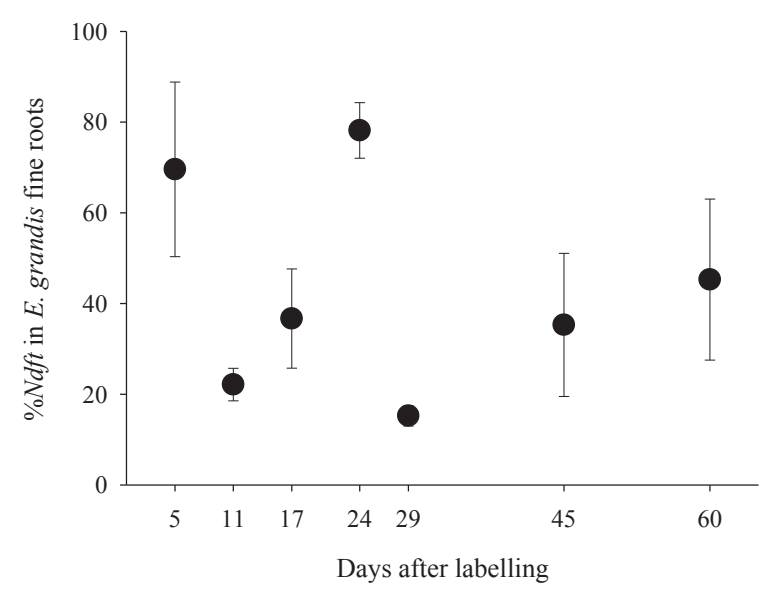

Fig. 7. Estimates of the percentage of Eucalyptus grandis nitrogen derived from Acacia mangium (\%NDFT) for 5, 11, 17, 24, 29, 45 and 60 days after Acacia labeling. Vertical bars indicate standard errors between individual estimates $(n=6)$. The mean \%NDFT value during the 60 day study period was $43.2 \%$.

\section{Discussion}

\subsection{A suitable method for ${ }^{15} \mathrm{~N}$ labeling donor trees}

${ }^{15} \mathrm{~N}$ pulse labeling aims to monitor the fate of ${ }^{15} \mathrm{~N}$ without modifying the $\mathrm{N}$ status of the target species (He et al., 2006). $\approx 0.9 \mathrm{~g}$ ${ }^{15} \mathrm{~N}-\mathrm{NO}_{3}$ was injected into the Acacia stem representing $0.85 \%$, $0.74 \%$ and $0.94 \%$ of the crown $\mathrm{N}$ (estimated from destructive sampling of leaves and branches 2 months after labeling: see Table 1 in Supplementary material). These percentages were close to the $1 \%$ concentration of crown $\mathrm{N}$ proposed by Swanston and Myrold (1998). The low amount of $\mathrm{N}$ injected did not significantly increase the $\mathrm{N}$ concentration of the leaves and fine roots of the labeled Acacia trees over the study period (see Table 2 in Supplementary material). However, high $\delta^{15} \mathrm{~N}$ values in the rhizosphere 5 days after labeling may have resulted from an initial increase in $\mathrm{N}$ root exudates, consistent with the slight enrichment of the soil $\mathrm{N}$ after foliar ${ }^{15} \mathrm{~N}$-labeling of Medicago sativa and Trifolium subterraneum plants (Gardener et al., 2012). An increase in N exudates owing to the damage to the tree cannot be excluded (Hale and More, 1979). In our experiment, ${ }^{15} \mathrm{~N}$-enriched nitrate exchanges between xylem and phloem saps may also have occurred after injection in the stem (Pate et al., 1998; Peuke et al., 2013), which would explain the rapid increase in ${ }^{15} \mathrm{~N}$ in the rhizosphere.

The stem injection method made it possible to label Acacia leaves rapidly. The same technique was used to label 20-year-old Picea sitchensis (Nair et al., 2014) where the average $\delta^{15} \mathrm{~N}$ within the needles was $4850 \%$, 4.5 months after injection. In our experiment, there was a high ${ }^{15} \mathrm{~N}$ enrichment of young Acacia leaves from 5 days after labeling (Fig. 4) which suggests a rapid transport of ${ }^{15} \mathrm{~N}-\mathrm{NO}_{3}^{-}$ to the foliage by mass flow (Millard et al., 2006; Augusto et al., 2011). However, the rise in $\delta^{15} \mathrm{~N}$ within the Acacia leaves up to 17 days after labeling suggests that other processes were involved in the accumulation of ${ }^{15} \mathrm{~N}$ in the leaves. A reduction of injected nitrate in the stem (Black et al., 2002; Miller and Cramer, 2005) leading to the production of ${ }^{15} \mathrm{~N}$-enriched amino acids (Pfautsch et al., 2009) transported in the xylem sap to the leaves could explain why ${ }^{15} \mathrm{~N}$ concentrations continued to increase after the rapid mass flow of injected ${ }^{15} \mathrm{~N}-\mathrm{NO}_{3}^{-}$. The limited number of sampled leaves and a dilution effect depending on the size of Acacia trees (Swanston and Myrold, 1998) may have accounted for the high $\delta^{15} \mathrm{~N}$ variability in the young Acacia leaves between blocks.

\subsection{Evidence of short-term $N$ transfer belowground}

In agreement with our first hypothesis, $\mathrm{N}$ was rapidly transferred belowground since ${ }^{15} \mathrm{~N}$ enrichment was already detectable in fine Eucalyptus roots 5 days after labeling. Large differences in $\delta^{15} \mathrm{~N}$ values in the young Eucalyptus leaves sampled probably reflected high $\delta^{15} \mathrm{~N}$ variability in the crown. ${ }^{15} \mathrm{~N}$ dilution during translocation of $\mathrm{N}$ compounds from roots to leaves (He et al., 2006) could explain the sharp decrease in $\delta^{15} \mathrm{~N}$ values observed from the stem to the canopy of Eucalyptus trees (Table 1). This variability and the low number of replicates ( 6 per distance from labeled Acacia trees for a given date) led to non-significant ${ }^{15} \mathrm{~N}$ enrichment of the young Eucalyptus leaves on some sampling dates (Fig. 6). However, the $\delta^{15} \mathrm{~N}$ in young Eucalyptus leaves was higher in most of the samples than the maximum $\delta^{15} \mathrm{~N}$ background value $(2.19 \%)$. The increase in $\delta^{15} \mathrm{~N}$ values during the study period was proportionally higher in fine Eucalyptus roots than in young Eucalyptus leaves. This pattern might be linked to ${ }^{15} \mathrm{~N}$ enrichment in fine roots relative to leaves (Pardo et al., 2012; Craine et al., 2015), consistent with $\delta^{15} \mathrm{~N}$ background values of $2.38 \%$ in the fine roots and $1.53 \%$ in the young leaves of the Eucalyptus trees sampled in our study. Despite a high variability within the crown, the effect of the distance from the 
labeled trees tended to be more pronounced for young leaves than for fine roots. The lack of precipitation between the ${ }^{15} \mathrm{~N}$ labeling and the sampling of fine roots and leaves 5 days after labeling shows that the short-term $\mathrm{N}$ transfer cannot be explained by an uptake of ${ }^{15} \mathrm{~N}$-rich compounds dissolved in Acacia throughfall and stemflow.

Direct and indirect routes might account for the short-term $\mathrm{N}$ transfer observed belowground between $A$. mangium and $E$. grandis trees. As found for carbon (Simard et al., 1997; Fitter et al., 1998) and for phosphorus (Wilson et al., 2006; Teste et al., 2014), N transfer may occur when plants are directly connected through common mycorrhizal networks (CMN) (e.g. Ingleby et al., 2007). Such a transfer was observed in a greenhouse experiment between Nitrogen Fixing Trees (NFT) and non-NFT (He et al., 2004, 2005), and in the field between Pinus sabiniana and Quercus douglasii (He et al., 2006), and Pseudotsuga menziesii tree and seedlings (Teste et al., 2009). In our experiment, $N$ may have been transferred between Acacia and Eucalyptus via CMNs since both A. mangium and E. grandis roots can be colonized by ectomycorrhizal Pisolithus sp. and Scleroderma sp. (Founoune et al., 2002; Duponnois and Plenchette, 2003; Ducousso et al., 2012). As in other subtropical forests (Toju et al., 2014), Acacia and Eucalyptus roots in our experiment were colonized by both arbuscular mycorrhizas and ectomycorrhizas in the 0-10 cm soil layer (Bini, 2012; Pereira, 2014).

Root exudation of $\mathrm{N}$ compounds could also be a major pathway for direct $\mathrm{N}$ transfer from Acacia to Eucalyptus trees. $\mathrm{N}$ exudates, mainly ammonium, amino acids and ureides, may account for up to $70 \%$ of the total $\mathrm{N}$ of annual legumes, and constitute a source of $\mathrm{N}$ that can be rapidly taken up by neighboring plants (Wichern et al., 2008; Fustec et al., 2010). In our experiment, N exuded by Acacia trees might be expected to be taken up by Eucalyptus trees. Significant ${ }^{15} \mathrm{~N}$ enrichment of the rhizosphere of both species was observed in our experiment from 5 days after labeling. $\delta^{15} \mathrm{~N}$ values were of the same magnitude in the Acacia and Eucalyptus rhizospheres (Fig. 5c, d), despite much higher ${ }^{15} \mathrm{~N}$ enrichment of fine Acacia roots than of fine Eucalyptus roots (Fig. 5a, b). This pattern could be related to the dense entanglement of the roots of the two species, as observed when separating the roots in the laboratory, causing rapid $\mathrm{N}$ exchange between the rhizospheres. Soil $\mathrm{N}$ inputs in the soil derived from exudation decrease drastically in the first few millimeters from the plant fine roots (Merbach et al., 1999; Schenck zu Schweinsberg-Mickan et al., 2010, 2012). The capacity of fine Eucalyptus roots to take up rapidly large amounts of $\mathrm{N}$ released in the vicinity of fine Acacia roots could, therefore, help to explain the dense intermingling of roots of the two species in the upper soil layer which helps to increase $\mathrm{N}$ transfer (Xiao et al., 2004). The similar values of $\delta^{15} \mathrm{~N}$ in the rhizosphere at a distance of $0.75 \mathrm{~m}$ and $2.25 \mathrm{~m}$ from the labeled Acacia trees, despite generally higher ${ }^{15} \mathrm{~N}$ enrichment of fine Acacia roots at a distance of $0.75 \mathrm{~m}$ than at $2.25 \mathrm{~m}$ could reflect the high $\mathrm{N}$ uptake by Eucalyptus roots in the first years after planting (Laclau et al., 2010). Time series analysis of changes in the soil solution have clearly shown a very fast uptake of nutrients by fine Eucalyptus roots in the top soil (Laclau et al., 2004, 2010; Mareschal et al., 2013), which might prevent ${ }^{15} \mathrm{~N}$ accumulation in the rhizosphere. A $\operatorname{similar}{ }^{15} \mathrm{~N}$ enrichment of the rhizosphere at the 2 distances from the labeled Acacia trees sampled during periods with low rainfall and low soil moisture (24-29 days after labeling) as well as during periods with high rainfall and high soil moisture (11-17 days after labeling) suggest that the amounts of $\mathrm{N}$ released by the Acacia roots leached below the $0-10 \mathrm{~cm}$ soil layer were low relative to the uptake by neighboring trees.

Rapid transfer of $\mathrm{N}$ might also occur indirectly through quick turn-over of very fine roots or of mycorrhizal hyphae of Acacia trees (Staddon et al., 2003). Furthermore, very rapid decomposition of nodules cannot be excluded: the half-life of Erythrina variegata and
G. sepium nodules decomposing in litterbags varied from 3 to 5 days in tropical conditions (Nygren et al., 2000).

A mass balance approach was used to give a rough estimate that approx. $3 \%$ of the amount of ${ }^{15} \mathrm{~N}$ injected into the stem of each labeled Acacia tree was transferred within 2 months to the neighboring Eucalyptus trees within a radius of $6.2 \mathrm{~m}$. This probably under-estimated the amount of ${ }^{15} \mathrm{~N}$ transferred since account was not taken of a possible increase in Eucalyptus tree $\mathrm{N}$ content during the study period (eq. (2)), as well as the ${ }^{15} \mathrm{~N}$ transfer to big and medium-sized roots, and very deep fine roots (at depths $>2 \mathrm{~m}$ ). This rapid ${ }^{15} \mathrm{~N}$ transfer would be consistent with significant shortterm belowground $\mathrm{N}$ transfer to Eucalyptus trees. High percentages of $\mathrm{N}$ derived from transfer (\%NDFT) in this study also suggest that $\mathrm{N}$ transfer from Acacia to Eucalyptus trees is an important facilitation process in the mixed species stand. However, \%NDFT was probably overestimated using equation (8), with a mean \% NDFT value of $78 \%$ at 24 days, and some individual \%NDFT estimates of $100 \%$. While the ${ }^{15} \mathrm{~N}$ compounds transferred from Acacia to Eucalyptus trees were considered to have the $\delta^{15} \mathrm{~N}$ signature of A. mangium fine roots in equation (8), large uncertainties in the patterns of belowground Acacia $\mathrm{N}$ transfer (from root exudates, mycorrhizal hyphae...) and in ${ }^{15} \mathrm{~N}$ discrimination during this process (Craine et al., 2015) prevented any reliable estimate of \%NDFT in our study. \%NDFT values in pot experiments usually range between 1 and 15\% (Chalk et al., 2014). However, up to 32\% of $\mathrm{N}$ derived from transfer was reported in E. maculata seedlings associated with $C$. cunninghamia in two-chambered containers (He et al., 2005). Our study was conducted on 2-year-old trees that might give significantly different results from young seedlings as shown by experiments on $E$. maculata and C. cunninghamia where the \%NDFT at 12 months was double that at 6 months of age (He et al., 2004, 2005).

\subsection{Short-term $N$ transfer at long distance from Acacia trees}

$\mathrm{N}$ was mainly released belowground close to the trunk of the labeled Acacia trees. Fine Acacia roots were ${ }^{15} \mathrm{~N}$ enriched at a distance of $0.75 \mathrm{~m}$ and $2.25 \mathrm{~m}$, with mean $\delta^{15} \mathrm{~N}$ values of $178 \%$ and $41 \%$, respectively. By contrast, fine Acacia roots had $\delta^{15} \mathrm{~N}$ values of only $4 \%$ at $3.8-5.3 \mathrm{~m} 60$ days after labeling (Fig. 5a), showing that the horizontal growth of fine Acacia roots was likely restricted to the first few meters from the Acacia stem.

Some compartments of the Eucalyptus trees as far as $6.2 \mathrm{~m}$ from the labeled Acacia trees showed signs of ${ }^{15} \mathrm{~N}$ enrichment (Table 1 and Fig. 6) indicating that short-term $\mathrm{N}$ transfer was not restricted to the Eucalyptus trees located in the immediate vicinity of the labeled Acacia trees (hypothesis 2). The capacity of 2-year-old Eucalyptus trees to take up $\mathrm{N}$ released by Acacia roots at a distance of 5-6 $\mathrm{m}$ is consistent with the rapid growth of $E$. grandis roots shown by Christina et al. (2011). Rapid transfer of $\mathrm{N}$ within fine Eucalyptus roots was shown by the $\delta^{15} \mathrm{~N}$ values at $3.8-5.3 \mathrm{~m}$ from the labeled trees being close to those at 0.75 and $2.25 \mathrm{~m}$ (Fig. $5 \mathrm{~b}$ ).

\section{Conclusion}

Direct injection of ${ }^{15} \mathrm{~N}$ into the xylem as used in our study was shown to be suitable for pulse ${ }^{15} \mathrm{~N}$ labeling of Acacia trees. This method could be useful for tracing belowground $\mathrm{N}$ transfer between tree species in other mixed forests. We showed, for the first time in the field, the short-term belowground transfer of nitrogen from nitrogen fixing trees to neighboring trees. Nitrogen was transferred belowground to Eucalyptus trees within a radius of $6 \mathrm{~m}$ around Acacia trees, from 5 days after labeling. This suggests that this facilitation process may promote $\mathrm{N}$ nutrition of non-NFTs growing in unfertile tropical soils when the fine roots of NFTs and 
non-NFTs are intermingled or are directly connected through common mycorrhizal networks.

\section{Conflict of interests}

\section{No conflict of interests declared.}

\section{Acknowledgments}

We would like to thank São Paulo Research fundation (FAPESP), grant 2011/20510-8 and grant 2010/16623-9, Intens\&fix Project (ANR-2010-STRA-004-03) and ATP Neucapalm (CIRAD) for their financial support. We would also like to thank Rildo Moreira e Moreira (USP-Esalq), Eder Araujo da Silva (www.floragroapoio.com. br) and the staff at the Itatinga experimental station and Cena laboratories for their technical support.

\section{Appendix A. Supplementary data}

Supplementary data related to this article can be found at http:// dx.doi.org/10.1016/j.soilbio.2015.08.017.

\section{References}

Augusto, L., Zeller, B., Midwood, A.J., Swanston, C., Dambrine, E., Schneider, A. Bosc, A., 2011. Two-year dynamics of foliage labelling in 8-year-old Pinus pinaster trees with ${ }^{15} \mathrm{~N},{ }^{26} \mathrm{Mg}$ and ${ }^{42} \mathrm{Ca}$ - simulation of Ca transport in xylem using an upscaling approach. Annals of Forest Science 68, 169-178.

Barrie, A., Prosser, S.J., 1996. Automated analysis of light-element stable isotope ratio mass spectrometry. In: Boutton, T.W., Yamasaki, S. (Eds.), Mass Spectrometry of Soils. Marcel Dekker, New York, USA, pp. 1-46.

Batterman, S.A., Hedin, L.O., van Breugel, M., Ransijn, J., Craven, D.J., Hall, J.S., 2013. Key role of symbiotic dinitrogen fixation in tropical forest secondary succession. Nature 502, 224-227.

Bini, D., 2012. Atributos microbianos e químicos do solo e da serapilheira em plantios puros e mistos de Eucalyptus grandis e Acacia mangium (PhD thesis). São Paulo University, Piracicaba.

Bini, D., Santosa, C.A., Bouillet, J.P., Gonçalves, J.L.M., Cardoso, E.J.B.N., 2013. Eucalyptus grandis and Acacia mangium in monoculture and intercropped plantations: evolution of soil and litter microbial and chemical attributes during early stages of plant development. Applied Soil Ecology 63, 57-66.

Binkley, D., Giardina, C., 1997. Nitrogen fixation in tropical forest plantations. Management of Soil, Nutrients and Water in Tropical Plantation Forests. In: ACIAR Monograph Series, pp. 297-337.

Binkley, D., Senock, R., Bird, S., Cole, T.G., 2003. Twenty years of stand development in pure and mixed stands of Eucalyptus saligna and nitrogen-fixing Facaltaric moluccana. Forest Ecology and Management 182, 93-102.

Black, B.L., Fuchigami, L.H., Coleman, G.D., 2002. Partitioning of nitrate assimilation among leaves, stems and roots of poplar. Tree Physiology 22, 717-724.

Blaser, W.J., Shanungu, G.K., Edwards, P.J., Venterink, H.O., 2014. Woody encroachment reduces nutrient limitation and promotes soil carbon sequestration. Ecology and Evolution 4, 1423-1438.

Bouillet, J.P., Laclau, J.P., Arnaud, M., Thongo, A., 2002. Changes with age in the spatial distribution of roots of a Eucalyptus clone in the Congo. Impact on wate and nutrient uptake ability. Forest Ecology and Management 171, 43-57.

Bouillet, J.P., Laclau, J.P., Gonçalves, J.L.M., Moreira, M.Z., Trivelin, P.C.O., Joudan, C., Silva, E.V., Piccolo, M.C., Tsai, S.M., Galiana, A., 2008. Mixed-species plantations of Acacia mangium and Eucalyptus grandis in Brazil 2. Nitrogen accumulation in the stands and biological $\mathrm{N}_{2}$ fixation. Forest Ecology and Management 255, 3918-3930.

Bouillet, J.P., Laclau, J.P., Gonçalves, J.L.M., Voigtlaender, M., Gava, J.L., Leite, F.P. Hakamada, R., Mareschal, L., Mabiala, A., Tardy, F., Levillain, J., Deleporte, P. Epron, D., Nouvellon, Y., 2013. Eucalyptus and Acacia tree growth over entire rotation in single- and mixed-species plantations across five sites in Brazil and Congo. Forest Ecology and Management 301, 89-101.

Catchpoole, D.W., Blair, G.J., 1990. Forage tree legumes. II. Investigation of nitrogen transfer to an associated grass using a split-plot technique. Australian Journal of Agricultural Research 41, 531-537.

Chalk, P.M., Peoples, M.B., McNeill, A.M., Boddey, R.M., Unkovich, M.J., Gardener, M.J., Silva, C.F., Chen, D., 2014. Methodologies for estimating nitrogen transfer between legumes and companion species in agro-ecosystems: a review of ${ }^{15} \mathrm{~N}$-enriched techniques. Soil Biology \& Biochemistry 73, 10-21.

Christina, M., Laclau, J.P., Goncalves, J.L.M., Jourdan, C., Nouvellon, Y., Bouillet, J.P., 2011. Almost symmetrical vertical growth rates above and below ground in one of the world's most productive forests. Ecosphere 2 art27.
Cliquet, J.B., Murray, P.J., Boucaud, J., 1997. Effect of the arbuscular mycorrhizal fungus Glomus fasciculatum on the uptake of amino nitrogen by Lolium perenne. New Phytologist 137, 345-349.

Craine, J.M., Brookshire, E.N.J., Cramer, M.D., Hasselquist, N.J., Koba, K., MarinSpiotta, E., Wang, L., 2015. Ecological interpretations of nitrogen isotope ratios of terrestrial plants and soil. Marschner review Plant and Soil 1-26. http:// dx.doi.org/10.1007/s11104-015-2542-1.

Daudin, D., Sierra, J., 2008. Spatial and temporal variation of below-ground N transfer from a leguminous tree to an associated grass in an agroforestry system. Agriculture, Ecosystems and Environment 126, 275-280.

Ducousso, M., Duponnois, R., Thoen, D., Prin, Y., 2012. Diversity of ectomycorrhizal fungi associated with Eucalyptus in Africa and Madagascar. International Journal of Forestry Research 2012, 1-10.

Duponnois, R., Plenchette, C., 2003. A mycorrhiza helper bacterium enhances ectomycorrhizal and endomycorrhizal symbiosis of Australian Acacia species. Mycorrhiza 13, 85-91.

FAO, 2010. Global Forest Resources Assessment. URL. http://www.fao.org/forestry/ fra/fra2010/en/.

Fellbaum, C.R., Mensah, J.A., Cloos, A.J., Strahan, G.E., Pfeffer, P.E., Kiers, E.T., Bücking, H., 2014. Fungal nutrient allocation in common mycorrhizal networks is regulated by the carbon source strength of individual host plants. New Phytologist 203, 646-656.

Fitter, A.H., Graves, J.D., Watkins, N.K., Robinson, D., Scrimgeour, C., 1998. Carbon transfer between plants and its control in networks of arbuscular mycorrhizas. Functional Ecology 12, 406-418.

Forrester, D.I., Pares, A., O'Hara, C., Khanna, P.K., Bauhus, J., 2013. Soil organic carbon is increased in mixed-species plantations of Eucalyptus and nitrogen-fixing Acacia. Ecosystems 16, 123-132.

Forrester, D.I., 2014. The spatial and temporal dynamics of species interactions in mixed-species forests: from pattern to process. Forest Ecology and Management 312, 282-292.

Founoune, H., Duponnois, R., Bâ, A.M., 2002. Ectomycorrhization of Acacia mangium, Willd. and Acacia holosericea, A. Cunn. ex G. Don in Senegal. Impact on plant growth, populations of indigenous symbiotic microorganisms and plant parasitic nematodes. Journal of Arid Environments 50, 325-332.

Fustec, J., Lesuffleur, F., Mahieu, S., Cliquet, J.B., 2010. Nitrogen rhizodeposition of legumes. A review. Agronomy for Sustainable Development 30, 57-66.

Gardener, M., Peoples, M., Condon, J., Li, G., Conyers, M., Dear, B., 2012. Evaluating the importance of a potential source of error when applying shoot ${ }^{15} \mathrm{~N}$ labelling techniques to legumes to quantify the below-ground transfer of nitrogen to other species. In: Yunusa, I. (Ed.), Proceedings of 16th Australian Agronomy Conference, 14-18 October 2012, Armidale, NSW.

Gilmour, A.R., Gogel, B.J., Cullis, B.R., Welham, S.J., Thompson, R., 2005. ASReml User Guide Release 2.0. VSN International Ltd, Hemel Hempstead HP1 1ES.

Gonçalves, J.L.M., Alvares, C.A., Higa, A.R., Silva, L.D., Alfenas, A.C., Stahl, J., Ferraz, S.F.B., Lima, W.P., Brancalion, P.H.S., Hubner, A., Bouillet, J.-P., Laclau, J.-P., Nouvellon, Y., Epron, D., 2013. Integrating genetic and silvicultural strategies to minimize abiotic and biotic constraints in Brazilian eucalypt plantations. Forest Ecology and Management 301, 6-27.

Hale, M.G., More, L.D., 1979. Factors influencing root exudation II - 1970-1978. Advances in Agronomy 31, 93-120. Academic Press Inc, New York.

He, X., Critchley, C., Ng, H., Bledsoe, C., 2004. Reciprocal N ( ${ }^{15} \mathrm{NH}_{4}^{+}$or $\left.{ }^{15} \mathrm{NO}_{3}^{-}\right)$transfer between non $\mathrm{N}_{2}$-fixing Eucalyptus maculata and $\mathrm{N}_{2}$-fixing Casuarina cunninghamiana linked by the ectomycorrhizal fungus Pisolithus sp. New Phytologist 163, 629-640.

He, X., Critchley, C., Ng, H., Bledsoe, C., 2005. Nodulated $\mathrm{N}_{2}$-fixing Casuarina cunninghamiana is the sink for net $\mathrm{N}$ transfer from non- $\mathrm{N}_{2}$-fixing Eucalyptus maculata via an ectomycorrhizal fungus Pisolithus sp. using ${ }^{15} \mathrm{NH}_{4}^{+}$or ${ }^{15} \mathrm{NO}_{3}^{-}$ supplied as ammonium nitrate. New Phytologist 167, 897-912.

He, X., Bledsoe, S.C., Zasoski, R.J., Southworth, D., Horwath, W.R., 2006. Rapid nitrogen transfer from ectomycorrhizal pines to adjacent ectomycorrhizal and arbuscular mycorrhizal plants in a California oak woodland. New Phytologist $170,143-151$.

He, X., Xu, M., Qiu, G.Y., Zhou, J., 2009. Use of ${ }^{15} \mathrm{~N}$ stable isotope to quantify nitrogen transfer between mycorrhizal plants. Journal of Plant Ecology 2, 107-118.

Hinsinger, P., Plassard, C., Jaillard, B., Tang, C., 2003. Origins of root-mediated pH changes in the rhizosphere and their responses to environmental constraints: a review. Plant and Soil 248, 43-59.

Hoogmoed, M., Cunningham, S.C., Baker, P., Beringer, J., Cavagnaro, T.R., 2014. Nfixing trees in restoration plantings: effects on nitrogen supply and soil microbial communities. Soil Biology \& Biochemistry 77, 203-212.

Ingleby, K., Wilson, J., Munro, R.C., Cavers, S., 2007. Mycorrhizas in agroforestry: spread and sharing of arbuscular mycorrhizal fungi between trees and crops: complementary use of molecular and microscopic approaches. Plant and Soil 294, 125-136.

Isaac, M.E., Hinsinger, P., Harmand, J.M., 2012. Nitrogen and phosphorus economy of a legume tree-cereal intercropping system under controlled conditions. Science of the Total Environment 434, 71-78.

Jalonen, R., Nygren, P., Sierra, J., 2009. Transfer of nitrogen from a tropical legume tree to an associated fodder grass via root exudation and common mycelial networks. Plant, Cell and Environment 32, 1366-1376.

Jones, D.L., Hodge, A., Kuzyakov, Y., 2004. Plant and mycorrhizal regulation of rhizodeposition. New Phytologist 163, 459-480.

Kähkölä, A.K., Nygren, P., Leblanc, H.A., Pennanen, T., Pietikäinen, J., 2012. Leaf and root litter of a legume tree as nitrogen sources for cacaos with different root 
colonisation by arbuscular mycorrhizae. Nutrient Cycling in Agroecosystems 92, $51-65$.

Kenward, M.G., Roger, J.H., 1997. The precision of fixed effects estimates from restricted maximum likelihood. Biometrics 53, 983-997.

Koutika, L.S., Epron, D., Bouillet, J.P., Mareschal, L., 2014. Changes in N and C concentrations, soil acidity and P availability in tropical mixed acacia and eucalypt plantations on a nutrient-poor sandy soil. Plant and Soil 379, 205-216.

Laclau, J.P., Toutain, F., Thongo, M'Bou, A., Arnaud, M., Joffre, R., Ranger, J., 2004. The function of the superficial root mat in the biogeochemical cycles of nutrient in congolese Eucalyptus plantations. Annals of Botany 93, 249-261.

Laclau, J.P., Bouillet, J.P., Gonçalves, J.L.M., Silva, E.V., Jourdan, C., Cunha, M.C.S., Moreira, M.R., Saint-André, L., Maquère, V., Nouvellon, Y., Ranger, J., 2008. Mixed-species plantations of Acacia mangium and Eucalyptus grandis in Brazil 1. Growth dynamics and aboveground net primary production. Forest Ecology and Management 255, 3905-3917.

Laclau, J.P., Almeida, J.C.R., Gonçalves, J.L.M., Saint-André, L., Ventura, M., Ranger, J., Moreira, R.M., Nouvellon, Y., 2009. Influence of nitrogen and potassium fertilization on leaf lifespan and allocation of above-ground growth in Eucalyptus plantations. Tree Physiology 29, 111-124.

Laclau, J.-P., Ranger, J., Gonçalves, J.L.M., Maquere, V., Krusche, A.V., M'Bou, A.T., Nouvellon, Y., Saint-André, L., Bouillet, J.-P., Piccolo, M.C., Deleporte, P., 2010. Biogeochemical cycles of nutrients in tropical Eucalyptus plantations. Forest Ecology and Management 259, 1771-1785.

Laclau, J.P., Nouvellon, Y., Reine, C., Gonçalves, J.L.M., Krusche, A.V., Jourdan, C., Le Maire, G., Bouillet, J.P., 2013a. Mixing Eucalyptus and Acacia trees leads to fine root over-yielding and vertical segregation between species. Oecologia 172, 903-913.

Laclau, J.P., Silva, E.A., Lambais, G.R., Bernoux, M., le Maire, G., Stape, J.L., Bouillet, J.P., Gonçalves, J.L.M., Jourdan, C., Nouvellon, Y., 2013b. Dynamics of soil exploration by fine roots down to a depth of $10 \mathrm{~m}$ throughout the entire rotation in Eucalyptus grandis plantations. Frontiers in Functional Plant Ecology 4 art. 243.

le Maire, G., Nouvellon, Y., Christina, M., Gonçalves, J.L.M., Bouillet, J.P., Laclau, J.P., 2013. Tree and stand light use efficiencies over a full rotation of mixed and pure Eucalyptus grandis and Acacia mangium plantations. Forest Ecology and Management 288, 31-42.

Lipson, D., Näsholm, T., 2001. The unexpected versatility of plants: organic nitrogen use and availability in terrestrial ecosystems. Oecologia 128, 305-316.

Mafongoya, P.L., Giller, K.E., Palm, C.A., 1998. Decomposition and nitrogen release patterns of tree prunings and litter. Agroforestry Systems 38, 77-97.

Manhães, C.M.C., Gama-Rodrigues, E.F., Silva-Moço, M.K., Gama-Rodrigues, A.C., 2013. Meso- and macrofauna in the soil and litter of leguminous trees in a degraded pasture in Brazil. Agroforestry Systems 87, 993-1004.

Mareschal, L., Laclau, J.P., Nzila, J.D.D., Versini, A., Koutika, L.S., Mazoumbou, J.C., Deleporte, P., Bouillet, J.P., Ranger, J., 2013. Nutrient leaching and deep drainage under Eucalyptus plantations managed in short rotations after afforestation of an African savanna: two 7-year time series. Forest Ecology and Management 307, 242-254.

Merbach, W., Mirus, E., Knof, G., Remus, R., Ruppel, S., Russow, R., Gransee, A., Schulze, J., 1999. Release of carbon and nitrogen compounds by plant roots and their possible ecological importance. Journal of Plant Nutrition and Soil Science 162, 373-383.

Millard, P., Wendler, R., Grassi, G., Grelet, G.A., Tagliavini, M., 2006. Translocation of nitrogen in the phloem of field-grown cherry and poplar trees during remobilization. Tree Physiology 26, 527-536.

Miller, A., Cramer, M., 2005. Root nitrogen acquisition and assimilation. Plant and Soil 274, 1-36.

Munroe, J.W., Isaac, M.E., 2014. N2-fixing trees and the transfer of fixed-N for sustainable agroforestry: a review. Agronomy for Sustainable Development 34, 417-427.

Nair, R., Weatherall, A., Perks, M., Mencuccini, M., 2014. Stem injection of ${ }^{15} \mathrm{~N}_{-} \mathrm{NH}_{4} \mathrm{NO}_{3}$ into mature Sitka spruce (Picea sitchensis). Tree Physiology 34, 1130-1140.

Nichols, J.D., Carpenter, F.L., 2006. Interplanting Inga edulis yields nitrogen benefits to Terminalia Amazonia. Forest Ecology and Management 233, 344-351.

Nygren, P., Lorenzo, A., Cruz, P., 2000. Decomposition of woody legume nodules in two tree/grass associations under contrasting environmental conditions. Agroforestry Systems 48, 229-244.

Nygren, P., Leblanc, H.A., 2009. Natural abundance of ${ }^{15} \mathrm{~N}$ in two cacao plantations with legume and non-legume shade trees. Agroforestry Systems 76, 303-315.

Nygren, P., Fernández, M., Harmand, J.M., Leblanc, H.A., 2012. Symbiotic dinitrogen fixation by trees: an underestimated resource in agroforestry systems? Nutrient Cycling in Agroecosystems 94, 123-160.

Nygren, P., Leblanc, H.A., 2015. Dinitrogen fixation by legume shade trees and direct transfer of fixed $\mathrm{N}$ to associated cacao in a tropical agroforestry system. Tree Physiology 35, 134-147.

O'Grady, A.P., Worledge, D., Battaglia, M., 2005. Temporal and spatial changes in fine root distributions in a young Eucalyptus globulus stand in southern Tasmania. Forest Ecology and Management 214, 373-383.

Pardo, L.H., Semaoune, P., Schaberg, P.G., Eagar, C., Sebilo, M., 2012. Patterns in $\delta^{15} \mathrm{~N}$ in roots, stems, and leaves of sugar maple and American beech seedlings, saplings, and mature trees. Biogeochemistry 112, 275-291.

Parrotta, J.A., Baker, D.D., Fried, M., 1996. Changes in dinitrogen fixation in maturing stands of Casuarina equisetifolia and Leucaena leucocephala. Canadian Journal of Forest Research 26, 1684-1691.

Pate, J., Shedley, E., Arthur, D., Adams, M., 1998. Spatial and temporal variations in phloem sap composition of plantation-grown Eucalyptus globulus. Oecologia 117, 312-322.
Paynel, F., Murray, P.J., Cliquet, J., 2001. Root exudates: a pathway for short-term N transfer from clover and ryegrass. Plant and Soil 229, 235-243.

Paynel, F., Cliquet, J., 2003. N transfer from white clover to perennial ryegrass, via exudation of nitrogenous compounds. Agronomie 23, 503-510.

Pereira, A.P.A., 2014. Influência da profundidade do solo e do manejo de Eucalyptus grandis e Acacia mangium na estrutura das comunidades microbianas do solo (MSc thesis). São Paulo University, Piracicaba.

Peuke, A.D., Gessler, A., Tcherkez, G., 2013. Experimental evidence for diel $\delta^{15} \mathrm{~N}$ patterns in different tissues, xylem and phloem saps of castor bean (Ricinus communis L.). Plant, Cell and Environment 36, 2219-2228.

Pfautsch, S., Gessler, A., Adams, M.A., Rennenberg, H., 2009. Using amino-nitrogen pools and fluxes to identify contributions of understory Acacia spp. to overstory Eucalyptus regnans and stand nitrogen uptake in temperate Australia. New Phytologist 183, 1097-1113.

Piotto, D., 2008. A meta-analysis comparing tree growth in monocultures and mixed plantations. Forest Ecology and Management 255, 781-786.

Proe, M.F., Midwood, A.J., Craig, J., 2000. Use of stable isotopes to quantify nitrogen, potassium and magnesium dynamics in young Scots pine (Pinus sylvestris). New Phytologist 146, 461-469.

Rachid, C.T.C.C., Balieiro, F.C., Peixoto, R.S., Pinheiro, Y.A.S., Piccolo, M.C., Chaer, G.M. Rosado, A.S., 2013. Mixed plantations can promote microbial integration and soil nitrate increases with changes in the N cycling genes. Soil Biology \& Biochemistry 66, 146-153.

Rao, A.V., Giller, E.G., 1993. Nitrogen fixation and its transfer from Leucaena to grass using ${ }^{15} \mathrm{~N}$. Forest Ecology and Management 61, 221-227.

Richards, A.E., Forrester, D.I., Bauhus, J., Scherer-Lorenzen, M., 2010. The influence of mixed tree plantations on the nutrition of individual species: a review. Tree Physiology 30, 1192-1208.

Schenck zu Schweinsberg-Mickan, M., Joergensen, R.G., Müller, T., 2010. Fate of ${ }^{13} \mathrm{C}-$ and ${ }^{15} \mathrm{~N}$-labelled rhizodeposition of Lolium perenne as function of the distance to the root surface. Soil Biology \& Biochemistry 42, 910-918.

Schenck Zu Schweinsberg-Mickan, M., Jörgensen, R.G., Müller, T., 2012. Rhizodeposition: its contribution to microbial growth and carbon and nitrogen turnover within the rhizosphere. Journal of Plant Nutrition and Soil Science 175, 750-760.

Sierra, J., Daudin, D., 2010. Limited ${ }^{15} \mathrm{~N}$ transfer from stem-labeled leguminous trees to associated grass in an agroforestry system. European Journal of Agronomy $32,240-242$.

Silva, E.V., Gonçalves, J.L.M., Coelho, S.R.F., Moreira, R.M., Mello, S.L.M., Bouillet, J.P., Jourdan, C., Laclau, J.P., 2009. Dynamics of fine root distribution after establishment of monospecific and mixed-species plantations of Eucalyptus grandis and Acacia mangium. Plant and Soil 325, 305-318.

Silva, E.V., Bouillet, J.P., Gonçalves, J.L.M., Abreu Junior, C.A., Trivelin, P.C.O. Hinsinger, P., Jourdan, C., Nouvellon, Y., Stape, J.L., Laclau, J.P., 2011. Functional specialization of Eucalyptus fine roots: contrasting potential uptake rates for nitrogen, potassium and calcium tracers at varying soil depths. Functional Ecology 25, 996-1006.

Simard, S.W., Perry, D.A., Jones, M.D., Myrold, D.D., Durall, D.M., Molinak, R., 1997. Net transfer of carbon between ectomycorrhizal tree species in the field. Nature 388, 579-582.

Staddon, P.L., Ramsey, C.B., Ostle, N., Ineson, P., Fitter, A.H., 2003. Rapid turnover of hyphae of mycorrhizal fungi determined by AMS microanalysis of ${ }^{14} \mathrm{C}$. Science 300, 1138-1140.

Sudmeyer, R.A., Simons, J.A., 2008. Eucalyptus globulus agroforestry on deep sands on the southeast coast of Western Australia: the promise and the reality. Agriculture, Ecosystems and Environment 127, 73-84.

Swanston, C.W., Myrold, D.D., 1998. Evaluation of the stem injection technique and subsequent ${ }^{15} \mathrm{~N}$ partitioning in red alder crowns. Plant and Soil 198, 63-69.

Teste, F.P., Simard, S.W., Durall, D.M., 2009. Role of mycorrhizal networks and tree proximity in ectomycorrhizal colonization of planted seedlings. Fungal Ecology 2, 21-30.

Teste, F.P., Veneklaas, E.J., Dixon, K.W., Lambers, H., 2014. Complementary plant nutrient-acquisition strategies promote growth of neighbour species. Functional Ecology 28, 819-828.

Toju, H., Sato, H., Tanabe, A.S., 2014. Diversity and spatial structure of belowground plant-fungal symbiosis in a mixed subtropical forest of ectomycorrhizal and arbuscular mycorrhizal plants. PLoS One 9, e86566.

Voigtlaender, M., Laclau, J.P., Goncalves, J.L.M., Piccolo, M.C., Moreira, M.Z., Nouvellon, Y., Ranger, J., Bouillet, J.P., 2012. Introducing Acacia mangium trees in Eucalyptus grandis plantations: consequences for soil organic matter stocks and nitrogen mineralization. Plant and Soil 352, 99-111.

Wacquant, J.P., Ouknider, M., Jacquard, P., 1989. Evidence for a periodic excretion of $\mathrm{N}$ by roots of grass-legume associations. Plant and Soil 116, 57-68.

Wichern, F., Eberhardt, E., Mayer, J., Joergensen, R.G., Müller, T., 2008. Nitrogen rhizodeposition in agricultural crops: methods, estimates and future prospects. Soil Biology \& Biochemistry 40, 30-48.

Wilson, G.W.T., Hartnett, D.C., Rice, C.W., 2006. Mycorrhizal-mediated phosphorus transfer between tallgrass prairie plants Sorghastrum nutans and Artemisia ludoviciana. Functional Ecology 20, 427-435.

Xiao, Y., Li, L., Zhang, F., 2004. Effect of root contact on interspecific competition and $\mathrm{N}$ transfer between wheat and fababean using direct and indirect ${ }^{15} \mathrm{~N}$ techniques. Plant and Soil 262, 45-54. 